\title{
Protective Role of Moringa Oleifera Lam Aqueous Leaf Extract on Some Excretory Products and Hematological Parameters in Acetaminophen Induced Albino Rats
}

\author{
H. C. C. Maduka, ${ }^{1,2}$, A. Daja ${ }^{1}$, G. A. Gadaka ${ }^{1}$, C. E. $\operatorname{Ugwu}^{2} *$, C. C. Dike ${ }^{2}$, K. A. \\ Abubakar $^{1}$, A. A. Maduka ${ }^{3}$ \\ ${ }^{I}$ Department of Biochemistry, University of Maiduguri, Borno State, Nigeria. \\ ${ }^{2}$ Department of Human Biochemistry, Nnamdi Azikiwe University, Nnewi Campus, Anambra State, Nigeria. \\ P.M.B. 4001, Post Code:435001. \\ ${ }^{3}$ Department of Gender Studies, University of Hull, England, United Kingdom.
}

\begin{abstract}
:
Background: Aqueous leaf extract of Moringa oleifera (MO) was evaluated for its ability to ameliorate acetaminophen-induced toxicity in albino rats using serum urea and creatinine levels as well as heamatological parameters as indices of evaluation.

Methods: Groups of five Albino rats were pre-administered with MO (200 and 400mg/kg/bw) prior to a single dose administration of acetaminophen (3g/kg body weight). Haematological and biochemical indices were determined using standard methods.

Results: Pretreatment of 200mg and $400 \mathrm{mg} / \mathrm{kg}$ body weight prior to acetaminophen administration caused significant reductions $(p<0.05)$ in the test groups when compared to normal control groups in the levels of urea and creatinine in serum. There were no significant difference in the haematological parameters between the test and control groups.
\end{abstract}

Conclusion: Results suggest that aqueous extract of Moringa oleifera administration would affect biological response to acetaminophen in kidney functions.

Key words: Moringa oleifera, Biochemical and Hematological Parameters, Acetaminophen.

\section{Introduction.}

The use of natural plant products in local folkloric medicine practice is gaining popular acceptance in the world especially in the orients and tropics like West and Southern Africa especially in Nigeria. Such plants include Sacoglottis gabonensis, a Nigerian alcoholic beverage additive $(1,2)$ and Moringa oleifera (unpublished). Moringa oleifera, horse radish tree is a pan-tropical species known by various regional names as benzolive, drumstick tree, kelor, marango, mulangay, nebedgy, saijhan and sajhan. Over the past two decades, many reports have described the nutritional and medicinal properties as well as its utility as a non-food product such as humbar, charcoal, fencing, water clarification and lubricating oil. Most of these reports need to be verified.

Moringa oleifera is the most widely cultivated species of a monogeneric family, the moringaceae which is native to the Sub-Himalayan tracts of India, Pakistan, Bangladesh and Afghanistan. It was utilized by the ancient Romans, Greeks and Egyptians and now is grown in tropical Asia, Latin America, Caribbean, Florida and Pacific Islands. All parts of Moringa, a perennial golf wood tree are edible and consumed by man. According to report of Fuglie(3) the many uses of Moringa included: alley cropping (biomass production), animal forage (leaves and treated seed-cake), biogas (from leaves), domestic cleaning agent(crushed leaves), blue dye (wood), fencing (Living trees), fertilizer (seed cake), foliar nutrient (juice expressed from the leaves), green manure (leaves), gum (tree trunks), honey and sugar cane juice-clarifier (powdered seeds), honey (flower nectar), medicine, ornamental plantings, biopepticide, pulp (wood), rope (bark), tanning for tanning hides (bark and gum) and Moringa seed oil for salads, fine machine lubrication and in the manufacture of perfume and hair care products (4). The tree has in recent times been advocated to be rich in cupious amounts of calcium, iron, vitamin $\mathrm{C}$ and digestible protein ( 3). Put together, Moringa has been advocated to play roles in nutrition, disease treatment and prevention such as in antibiotic therapy (H. pylori) and cancer $(5,6)$.

Notwithstanding, most of these reports have not been verified scientifically. A few scientific reports of Moringa oleifera are those of Pari and Kumar (7) on the hepatoprotective properties on antitubacular druginduced liver damage in rats, in vivo antioxidant activities after carbon tetrachloride induced liver damage (8), in vitro and in vivo antioxidant properties of different fractions of the leaves (9). 
Acetaminophen is an analgesic drug taken as a palliative against alcohol-induced headaches among consumers of alcohol. When taken in excess, it can be hepatotoxic (10). The report of Fakurazi et al. (11) indicated that Moringa oleifera exhibited cytoprotection in acetaminophen-induced rats and via restoration of glutathione levels. Hamza (12) reported protection against liver fibrosis while Sharifudin et al.(13) reported that Moringa extracts exhibited protection against acetaminophen-induced hepatotoxicity. None of the above work reported an effect on kidney functions, kidney toxicity or excretory products like urea and creatinine which are reliable estimable biomolecules of evaluation of kidney damage.

Though Sharifudin at a dose level of $7 \mathrm{~g} / \mathrm{kg}$ bodyweight of acetaminophen reported no change in urea and creatinine, there was no mention of the doses of the Moringa oleifera extracts they used in their investigation, thus limiting comparativity even though the paper still inferred hepatoprotective activity. This paper has, therefore, investigated the protective effects of Moringa oleifera aqueous leaf extract at 200 and $400 \mathrm{mg} / \mathrm{kg}$ body weight prior to a single dose intraperitoneal administration of acetaminophen at $3 \mathrm{~g} / \mathrm{kg}$ body weight on Wister albino rats using urea and creatinine as indices of effect on the kidney. It was also to relate the effects to any changes that could be observed in other tissues and blood observable parameters.

\section{Materials and methods.}

2.1. Collection and preparation of crude leaves extract of Moringa oleifera Lam.

The leaves of Moringa oleifera were collected within Maiduguri metropolis, Borno State Nigeria. The leaves were preserved in the Department of Biochemistry and dried at room temperature away from sunlight and made into powder using mortar and pestle. $50 \mathrm{~g}$ of the powdered leaves were weighed and poured into $500 \mathrm{ml}$ conical flask in which $200 \mathrm{ml}$ distilled water was added. The mixture was kept for 12 hours with constant agitation using a mechanical shaker at 30 minutes intervals. The extract was filtered using Whatman number 1 filter paper. The filtrate was concentrated in vaccuo with a rotary evaporator. The semi-solid extract obtained was stored in refrigerator for use. $0.11 \%$ yield of the extract was recorded which increased to $0.19 \%$ on refrigeration throughout the period of extraction.

\subsection{Animal treatment.}

Thirty albino rats aged 5 weeks were purchased from the Experimental Animal Unit of the Department of Biochemistry, University of Maiduguri and used for the study. The animals were handled in accordance to the rules and regulation by the Experimental Animal Care Committee Board, University of Maiduguri. The rats were of equal number of both sexes and weighed 80-130g. They were housed in rat cages in the Department of Biochemistry Laboratory. The rats were fed with commercial feed (Saunders Feed Nigeria Limited) and water ad libitum, and were acclimatized for one week in the laboratory before the experiment started. The rats were randomly divided into six groups (A, B,C,D,E, and F) of 5 animals each. A dose of $3 \mathrm{~g} / \mathrm{kg}$ bwt (11) was administered to induce hepatotoxicity. Rats in group A were given normal saline for 10 days and serves as control while rats in group B were administered normal saline for 9 days but were administered $3 \mathrm{~g} / \mathrm{kg}$ body weight of acetaminophen on the 10th day. Animals in groups $\mathrm{C}$ and D were given an oral administration of $200 \mathrm{mg}$ and $400 \mathrm{mg} / \mathrm{kg}$ body weight of the extract respectively for 10 days. The acetaminophen was also administered orally in saline as the medium. Rats in groups E and F were also administered with 200mg and $400 \mathrm{mg} / \mathrm{kg}$ body weight respectively of the extract for 9 days and on the 10 th day $3 \mathrm{~g} / \mathrm{kg}$ of acetaminophen was also given orally. At the end of the experiment, the animals were starved of food for 24 hours, anaesthetized with chloroform vapour, quickly brought out of the jar and blood samples collected via cardiac puncture.

\subsection{Estimation of hematological and biochemical parameters.}

The packed cell volume (PCV) was determined by the microhaematocrit method; the erythrocyte (RBC) and leucocytes (WBC) counts by the hemocytometer method and the haemoglobin concentration (Hb) by Sahli method (14). The serum creatinine was estimated by the modified method as described by Henry (15) while serum urea was determined enzymatically as described by Chaney and Marbach (16) using reagent kits supplied by Randox Laboratories, UK.

\subsection{Statistical analysis.}

The results are expressed as mean \pm standard deviation. The statistical evaluation of data was performed using one-way ANOVA followed by Duncan's multiple range test(s). The acceptable level of significance was $\mathrm{p}<0.05$.

\section{Results.}

\subsection{Effect of Moringa oleifera leaf extract on serum urea and creatinine levels.}

The results of the effect of Moringa oleifera leaf extract on acetaminophen-induced wister albino rats as evaluated by serum urea and creatinine levels is shown in Table 1. From the result, there was significant 
increase in the level of urea in the blood in acetaminophen-induced control Wister albino rats (group B) compared with the normal control group(A) and the other extract treated groups (C,D, E and F) suggesting that the extract reduced the metabolism and eventual excretion of urea. Similarly, the extract reduced the level of creatinine in extract treated groups (groups C,D,E and F) compared with the acetaminophen-treated control group (group $\mathrm{B}$ ) at $\mathrm{P}<0.05$ suggesting cytoprotection effect.

\subsection{Effect of Moringa oleifera leaf extract on acetaminophen induced wister albino rats by haematological parameters.}

The effect of aqueous leaf extract of Moringa oleifera in wister albino rats induced by acetaminophen administration as evidenced by haematological parameters is as detailed in Table 2. As can be seen from the table, prior administration of Moringa oleifera aqueous leaf extract spared the tissue Packed cell volume(PCV) significantly $(\mathrm{P}<0.05)$ in groups $\mathrm{C}, \mathrm{D}, \mathrm{E}$ and $\mathrm{F}$ as compared with the normal saline control (group $\mathrm{A}$ ) and acetaminophen test control group(B). This same trend of result was essentially observed in haemoglobin $(\mathrm{Hb})$ count and red blood cell (RBC) counts suggesting that the extract stabilized red cell maturation factors and protected against acetaminophen induced depletion. No much variation was observed in white blood cell (WBC) (total) counts suggesting that the extract may not have induced toxic responses in the induced Wister albino rats used. The extract had overwhelming influence in enhancing the RBC counts of extract treated groups in a manner suggesting dose-dependence relationship.

\section{Discussion.}

Acetaminophen, a commonly used analgesic and antipyretic drug (17) is a hepatotoxicant which indues liver enzymes (18) and causes hepatoinjury via its metabolite, N-acetyl-parabenzoquinoneimine $(19,20)$. In this research, the level of amelioration of Moringa oleifera leaf extract on acetaminophen-induced rats was investigated using urea and creatinine indicators of renal dysfunction and kidney failure by a toxic compound as indices of biochemical evaluation. Parameters such as the serum aminotransferases and alkaline phosphatase were not assayed having been addressed by previous reports(7-9,11). None of these studies reported effects involving the important excretory products of metabolism urea and creatinine. Sharinfudin et al.(12) did not report any reasonable change in the waste products after acetaminophen intoxication at $7 \mathrm{~g} / \mathrm{kg}$ body weight and still did not report on studies of $200 \mathrm{mg}$ and $400 \mathrm{mg}$ extract per kg body weight thus, limiting comparability. In the study being reported by this article, prior administration of aqueous leaf extract of Moringa oleifera reduced the acetaminophen-induced excretion of urea and creatinine, two excretory indices of biochemical evaluation of kidney and renal functions. Acetaminophen is a long proven xenobiotic oxidant which causes oxidative stress in animals (10). Lysosomal enzymes excreted in urine were used as non-invasive tests for renal damages (22) and these hydrolases catalyze the hydrolysis of glycoproteins, glycolipids and glycosaminoglycans (23) and may also act extracellualarly to break down endothelial membrane conjugates (24). The reduction in the amount of the excretory products, urea and creatinine would suggest protection against acetaminophen induction.

The above reduction seems to corroborate the observed reductions in the depletion of the heamatological parameters, RBC, WBC and Bb counts in this study. Xenobiotic oxidants cause elevations in lipid peroxides in red cells (25) and accompanying reductions in physiological parameters such as the above red cell maturation factors, RBC, WBC and HB $(2,21)$. The sparing of RBC and $\mathrm{Hb}$ by the aqueous leaf extract of Moringa oleifera suggests cytoprotection and antioxidant properties. Similarly, proliferation of WBC total count was inhibited by the crude extract. Proliferation of lymphocytes is the first stage of response to toxic challenges by oxidants and this observation shown by this set of results shows that the Moringa oleifera leaf extract is cytoprotective. This result shows a clear biological response to the administration of acetaminophen in the albino rats. The observed aparing of haematological parameters (WBC, RBC and $\mathrm{Hb}$ ) corroborated the stabilization of red cell maturation factors earlier reported by Maduka et al. (21) in a sister laboratory in Northen Nigeria by Sacoglottis gabonensis, a Nigerian alcoholic beverage additive after administration of pulmonary toxicant, methyl viologen.

The results of this study favour a conclusion that aqueous leaf extract of Moringa oleifera favour a conclusion that aqueous leaf extract of Moringa oleifera possesses cytoprotective properties against acetaminophen induced cytotoxicity and the mechanism of action seems to be via the complementing the utilization of $\mathrm{RBC}, \mathrm{Hb}$ and inhibition of WBC proliferation as well as inhibiting the production of urea and creatinine.

\section{Competing interest.}

Authors have declared that no competing interests exist. 


\section{References.}

[1]. Maduka H C C, Okoye Z S C. The effect of Sacoglottis gabonensis beverage additive on the natural antioxidant defences during 2, 4-dinitrophenyl hydrazine-induced membrane peroxidation in vivo. Vasc. Pharm. 39: 21-31. (2002)

[2]. Maduka H C C, Okoye Z S C, Eje, A. The influence of Sacglottis gabonensis stem bark extract and bergenin its isolate, Nigerian alcoholic beverage additives on the metabolic and haematological side effect of 2,4-dinitrophenyl hydrazine-induced tissue damage. Vasc. Pharm. 39(6): 317-324 (2003).

[3]. Fuglie L J. The miracle tree: Moringa oleifera. Natural Nutrition for the Tropics. Church World Service, Dakar. 68. Revised in 2001 and published as The Miracle Tree: The Multple attributes of Moringa. 1999. Pg.172. http:// www.echotech.org/bookstore/advanced search result.php?keywords=miracle+Tree.

[4]. Berger M R, Habs M, Jahn S A, Schmahl, S. Toxicological assessment of seeds from Moringa oleifera and Moringa stenoptala, two highly efficient primary coagulants for domestic water treatment of tropical raw waters. East Afr. Med. J. 61:712-716 (1984).

[5]. Akhtar A H, Ahmad K U. Anti-ulcerogenic evaluation of the dietary association of goiter in Gamo-Gofa, Ethiopia. East Afr. Med. J. 76: 447-451 (1995).

[6]. Anwar F, Bhanger M I. Analytical characterization of Moringa oleifera seed oil grown in temperate regions of Pakistan. J. Agric Food Chem. 51: 6558-6563(2003).

[7]. Pari L, Kumar N A. Hepatoprotective activity of Moringa oleifera an antitubucular drug-induced liver damage in rats. J. Med. Food.. 5(3):171-17 (2002).

[8]. Rakesh S, Singh V J. In vivo antioxidant activity of Ptoringa oleifera leaf and pod extracts against carbon tetrachloride induced liver damage in albino mice. J. Chem. Pharm. Res. 2(6):275-283(2010).

[9]. Arti R V, Vijayakumar M, Mathela C S, Rao C V. In vitro and In vivo antioxidant properties of different fractions of Moringa oleifera leaves. Food Chem. Toxicol. 47(9):2196-2201 (2009).

[10]. Madusolumuo M A, Okoye Z S C, Ayalogu E O. Effect of consumption of Sacoglottis gabonensis stem bark treated palm wine on disposition of acetaminophen in human volunteers. Biosci. Res. Commun. 5(10): 9-11(1993).

[11]. Fakurazi S, Hairuszah I, Nanthini U. Moringa oleifera Lam prevents acetaminophen induced liver injury through restoration of glutathione level. Food Chem. Toxicol. 46(8): 2611-2615(2008).

[12]. Hamza A.A. Ameliorative effects of Moringa oleifera Lam seed extract on liver fibrosis in rats. Food Chem. Toxicol. 48(1): 345355(2010)

[13]. Sharifudin S A, Fakurazi S, Hidayat M T, Hairuszah L, Moklas M A M, Arulselvan P. Therapeutic potential of Moringa oleifera extracts against acetaminophen-induced hepatotoxicity in rats. Pharm. Biol. 2013. 51(3):279-288.

[14]. Schalm O W, Jain N C, Carrol E J. Veterinary Haematology. $3^{\text {rd }}$ edition. Lea and Febiger, Philadelphia.22- 28 (1995).

[15]. Henry R J. Determination of creatinne. In: Clinical Chemistry, Principles and Techniques. Hargerstein, M.D. Harper and Row. 535(1974)

[16]. Chaney A L, Marbach E P. Modified reagent for determination of urea and ammonia. Clin. Chem. 8:130-132(196)2.

[17]. Fakurazi S, Nanthini U, Hairuszah I. Hepatoprotective and antioxidant action of Moringa oleifera Lam against acetaminophen induced hepatotoxicity in rats. Int. J. Pharm. 4(4): 270-275 (2008).

[18]. Ita S O, Akpanyung E O, Umoh B I, Ben E E, Ukafia S O. Acetaminophen induced hepatic toxicity: protective role of Ageratum conyzoides. Pakistan J. Nutr. 8 (7):928-932 (2009).

[19]. Wallace J L. Acetaminophen hepatotoxicity: No to the rescue. Brit. J. Pharmacol. 143(1):1- 2(2004).

[20]. Raucy J L, Lasker J M, Lieber C S, Black M C. Apap activation by human 212 liver cytochrome P4502EI and P450IA2. Arch Biochem Biophys. 271: 270-283 (1989).

[21]. Maduka H C C, Okoye Z S C, Ladeji O, Egbe P E. The protective role of Sacoglottis gabonensis stem bark extract against peroxidation reactions in vivo and in vitro. Nigeria Journal of Biotechnology. 10:1-8(1999).

[22]. Gatsing G, Garba I H, Adoga GI. The use of lysosomal enzymuria in the early detection and monitoring of the progression of diabetic nephropathy. Indian Journal of Clinical Biochemistry. 21(2):42-48(2006).

[23]. Adoga G I, Glew R H. lysosomal enzymes in the diagnosis and management of complications in diabetes mellitus. International Diabetes Digest. 12-15(.1995).

[24]. Goron O, Pearson J D. Sialic acid moieties on surface glycoproteins protect endothelial cells from prolytic damage. Journal of Pathology. 146:205-212(1985)

[25]. Maduka H C C, Okoye Z S C. Protective role of Sacoglottis gabonensis stembark extract on experimental membrane lipid peroxidation induced by 2,4-dinitrophenyl hydrazine. Nigerian Journal of botany. 22(2):297-307 (2002).

Table 1. Effect of aqueous Moringa oleifera leaf extract on serum urea and creatinine levels.

\begin{tabular}{|l|l|l|l|}
\hline \multirow{2}{*}{ Groups } & Treatment & \multicolumn{2}{|c|}{ Biochemical parameters } \\
\cline { 2 - 4 } & \multicolumn{1}{|c|}{$\begin{array}{l}\text { Serum Urea } \\
(\mathbf{m M o l} / \mathbf{L})\end{array}$} & $\begin{array}{l}\text { Serum } \\
\text { Creatinine }(\boldsymbol{\mu m o l} / \mathbf{L})\end{array}$ \\
\hline $\mathrm{A}$ & Normal saline only & $6.30 \pm 0.92$ & $128.50 \pm 5.44$ \\
\hline $\mathrm{B}$ & Normal saline + acetaminophen & $11.02 \pm 5.04^{*}$ & $151.50 \pm 40.03^{*}$ \\
\hline $\mathrm{C}$ & $200 \mathrm{mg} / \mathrm{kg}$ bwt. of Moringa oleifera. & $7.25 \pm 0.35$ & $123.75 \pm 10.04$ \\
\hline $\mathrm{D}$ & $400 \mathrm{mg} / \mathrm{kg}$ bwt. of Moringa oleifera & $6.62 \pm 0.50$ & $121.5 \pm 13.4$ \\
\hline $\mathrm{E}$ & $\begin{array}{l}200 \mathrm{mg} / \mathrm{kg} \text { bwt. of Moringa oleifera + 3g/kg bwt } \\
\text { acetaminophen }\end{array}$ & $7.23 \pm 1.46$ & $108.50 \pm 15.5$ \\
\hline $\mathrm{F}$ & $\begin{array}{l}400 \mathrm{mg} / \mathrm{kg} \text { bwt. of Moringa oleifera +3gkg/bwt. } \\
\text { acetaminophen }\end{array}$ & $7.72 \pm 1.62$ & \\
\hline
\end{tabular}

Bwt= body weight.

Results are mean \pm SD of triplicate determinations . Values with superscript in a column are statistically significant to the control $(\mathrm{p}<0.05)$. 
Protective Role Of Moringa Oleifera Lam Aqueous Leaf Extract On Some Excretory Products....

Table 2. Effect of Moringa oleifera aqueous leaf extract on haematology of acetaminophen-induced Wister albino rats.

\begin{tabular}{|c|c|c|c|c|c|}
\hline \multirow[t]{2}{*}{ Groups } & \multirow[t]{2}{*}{ Treatment } & \multicolumn{4}{|c|}{ Heamatological parameters. } \\
\hline & & $\operatorname{PCV}(\%)$ & $\mathrm{Hb}(\mathrm{g} / \mathrm{dl})$ & RBC $\left(\times 10^{6} \gamma^{-1}\right)$ & WBC $\left(\times 10^{3} \mathrm{~mm}^{-1}\right)$ \\
\hline A & Normal saline only & $0.30 \pm 0.04$ & $10.65 \pm 1.41$ & $4.55 \pm 1.26$ & $12.25 \pm 12.25$ \\
\hline $\mathrm{B}$ & $\begin{array}{l}\text { Normal saline } \\
\text { acetaminophen }\end{array}$ & $0.32 \pm 0.03$ & $11.5 \pm 0.86$ & $4.95 \pm 0.26$ & $11.25 \pm 1.08$ \\
\hline $\mathrm{C}$ & $\begin{array}{l}200 \mathrm{mg} / \mathrm{kg} \text { bwt. of Moringa } \\
\text { oleifera. }\end{array}$ & $0.36 \pm 0.03^{*}$ & $11.02 \pm 0.84$ & $6.02 \pm 0.30 *$ & $8.7 \pm 15.26$ \\
\hline $\mathrm{D}$ & $\begin{array}{l}400 \mathrm{mg} / \mathrm{kg} \text { bwt. of Moringa } \\
\text { oleifera }\end{array}$ & $0.40 \pm 0.08 *$ & $12.2 \pm 0.31 *$ & $6.97 \pm 0.36^{*}$ & $6.90 \pm 1.59$ \\
\hline $\mathrm{E}$ & $\begin{array}{l}200 \mathrm{mg} / \mathrm{kg} \text { bwt. of Moringa } \\
\text { oleifera }+3 \mathrm{~g} / \mathrm{kg} \text { bwt } \\
\text { acetaminophen }\end{array}$ & $0.32 \pm 0.03^{*}$ & $10.82 \pm 1.23$ & $5.12 \pm 1.12 *$ & $8.45 \pm 5.96$ \\
\hline $\mathrm{F}$ & $\begin{array}{l}400 \mathrm{mg} / \mathrm{kg} \text { bwt. of Moringa } \\
\text { oleifera }+\quad 3 \mathrm{gkg} / \mathrm{bwt} \text {. } \\
\text { acetaminophen }\end{array}$ & $0.34 \pm 0.03^{*}$ & $11.12 \pm 1.48 *$ & $6.15 \pm 1.50$ & $11.97 \pm 2.38$ \\
\hline
\end{tabular}

Results are mean \pm SD of triplicate determinations. Values with superscript in a column are statistically significant to the control $(\mathrm{P}<0.05)$. 